\title{
PAPUA NEW GUINEA: COUNTRY REPORT ON HUMAN RIGHTS
}

\author{
Freda Talao*
}

\section{INTRODUCTION}

Papua New Guinea (PNG) is the largest developing country in the Pacific. It gained its independence from Australia on 16 September 1975. With a population of about 6 million, it is made up of more than 600 islands. It has over 860 different languages and tribes with their own distinct cultures. Administratively, it is made up of 19 provinces and 89 districts including the Autonomous Government of Bougainville. About 87 per cent of the population of PNG live in rural areas. Accessibility to these rural areas is extremely difficult because of the rugged terrain. Most places are only accessible by air transport or on foot.

In 2008 PNG celebrated 33 years of independence. But whilst this independent and sovereign nation has managed to gain its independence without bloodshed (with the exception of the Bougainville crisis, post independence) and continues to have what many describe as a very robust democracy, the protection and enforcement of human rights remain critical issues.

Civil and political rights are enshrined in the Constitution, ${ }^{1}$ yet are not effectively enforced or realised because of procedural barriers. To make matters worse, socio-economic and cultural rights are expressed only as guiding principles rather than constitutional rights and are thus not enforceable in a court of law. ${ }^{2}$ PNG confers no economic rights on its weakest citizens, including the sick and disabled. There is no right of access to health and education. Illiteracy and a weak civil society have meant many human rights duty bearers, such as the government, have not been held to account for breaches or lack of enforcement of rights.

* Human Rights Lawyer and Activist and Chair, Individual and Community Rights Advocacy Forum (ICRAF). I would like to acknowledge the contributions of my colleagues, Ms Esther Gaegaming, Team Leader, Anti Corruption and Rights Unit of the PNG Ombudsman Commission; Ms Utul Marat, Legal Officer with the Department of Justice and Attorney-General and Damien Ase, Director of the Centre for Environmental Law and Community Rights (CELCOR).

1 Constitution of the Independent State of PNG available at www.paclii.org/.

2 Esther Gaegaming "Why did a Lawyer from Papua New Guinea Feel the 'Pressing Need' for Human Rights Training?" (2006) Spring/Summer Issue Commonwealth Matters www.commonwealth.sas.ac.uk/degrees (last accessed 1 June 2008). 
By not ratifying two important international human rights conventions - the International Convention on Civil and Political Rights (ICCPR) ${ }^{3}$ and the International Convention on Economic Social and Cultural Rights (ICESCR) ${ }^{4}$ - many of these rights remain open to abuse as the domestic framework for their protection and realisation remains weak. PNG ranks as one of the worst offenders in the Pacific region for human rights breaches. Apart from police brutality and domestic violence, there is now an alarming rate of killings, particularly in the Highlands Region, as a result of the practice of sorcery. Anecdotal evidence to date suggests that women are the main targets of these senseless killings.

Unfortunately, law enforcement agencies, including the police, turn a blind eye to sorcery related killings despite protests by non-government organisations (NGOs) and concerned citizens. Lack of witnesses compounds the problem as there is a general reluctance within communities to testify against alleged murderers, thus allowing the vicious cycle to continue. PNG is now at a crossroads. It needs to take deliberate steps to address many issues that will be highlighted in this paper.

\section{CONSTITUTIONAL STRUCTURE AND THE PROTECTION OF RIGHTS}

PNG has been extremely fortunate as a nation to have human rights as the foundation of its Constitution. In framing the Constitution, the Constitutional Planning Committee (CPC) declared human rights values, as set forth in the Universal Declaration of Human Rights, as the foundation on which the young nation of PNG was to be built, rejecting violence as a means of resolving conflict and declaring that every citizen was born equal and free. The CPC further ensured that these rights and freedoms were enforceable in a court of law.

In its Final Report, tabled in the House of Assembly in 1974, the CPC made the following observation, which provides an insight into the thinking underlying the development of the Constitution: ${ }^{5}$

We see the planning of our own constitution as a vital aspect of the process of determination. It is not just the matter of our people determining that they should govern themselves. We have the opportunity of determining how we shall govern ourselves. To answer this question, we must know what philosophy of life we wish to live by, what social and economic goals we wish to achieve, what kind of society we wish Papua New Guinea to be.

3 International Covenant on Civil and Political Rights (16 December 1966) 999 UNTS 171 [ICCPR].

4 International Covenant on Economic, Social and Cultural Rights (16 December 1966) 993 UNTS 3 [ICESCR].

5 Constitutional Planning Committee Final Report of the Constitutional Planning Committee Part 1 (Government Printer, Port Moresby, 1974). 
The kind of society the CPC wanted to see was one free from violence, where every person was allowed to grow, participate and enjoy the benefits this nation could offer.

The Constitution of PNG contains what are generally called the "National Goals and Directive Principles". These are guiding principles for governance and are non-justiciable. While not enforceable in a court of law per se, it is a requirement that all constitutional laws affecting the rights of an individual must have a reference point in these Goals and Principles.

\section{A The Preamble}

The Preamble provides that respect for the dignity of the individual and community interdependence are basic principles of society; that we guard with our lives, national identity, integrity and self respect; that we reject violence and seek consensus as a means of solving common problems and that national wealth, won by honest, hard work, be equitably shared by all.

\section{B The Five National Goals and Directive Principles}

The National Goals and Directive Principles direct all persons and bodies, incorporated and unincorporated, to be guided by the declared Directives in pursuing and achieving their aims.

\section{Integral human development}

The first Goal is for every person to be involved in the process of freeing himself or herself from every form of domination or oppression so that they will have the opportunity to develop as a whole person in relationship with others:

(1) They must be involved in endeavours to achieve integral human development of themselves and to seek fulfilment through their contribution to the common good;

(2) Education to be based on mutual respect and dialogue, and to promote awareness of human potential and motivation to achieve national goals through self-reliant efforts;

(3) All forms of beneficial creativity including sciences and cultures, to be actively encouraged;

(4) Improvement in the level of nutrition and the standard of public health to enable the people to attain self-fulfillment;

(5) The family unit to be recognised as the fundamental basis of society, and for every step to be taken to promote the moral, cultural, economic and social standing of the Melanesian family; and

(6) Development to take place primarily through the use of PNG forms of social and political organisation. 


\section{Equality and participation}

The second Goal is for all citizens to have an equal opportunity to participate in, and benefit from, the development of PNG through:

(1) An equal opportunity for every citizen to take part in the political, economic, social, religious and cultural life of the country;

(2) Equalisation of services in all parts of the country, and for every citizen to have equal access to legal processes and all services, governmental and otherwise, that are required for the fulfilment of his or her real needs and aspirations;

(3) Equal participation by women citizens in all political, economic, social and religious activities;

(4) The maximisation of the number of citizens participating in every aspect of development;

(5) Every citizen to be able to participate, either directly or through a representative, in the consideration of any matter affecting his interests or the interests of his community;

(6) All persons and governmental bodies to endeavour to achieve universal literacy in Tok Pisin, Hiri Motu or English, and in tokples; and

(7) Recognition of the principles that a complete relationship in marriage rests on equality of rights and duties of the partners, and that responsible parenthood is based on that equality.

\section{National sovereignty and self-reliance}

The Goal of national sovereignty and self-reliance was aimed mainly at protecting PNG from giving into pressures particularly from multinational interests that would undermine PNG's sovereignty, and to stop the use of public resources for personal gain.

\section{Natural resources and environment}

The need for sustainable human development and to sustain resources for future generations was an essential goal at the time of developing the Constitution.

\section{Papua New Guinean ways}

The fifth Goal is to achieve development primarily through the use of PNG forms of social, political and economic organisations including:

(1) A fundamental re-orientation of attitudes and the institutions of government, commerce, education, and religion towards Papua New Guinean forms of participation, consultation and consensus, and a continuous renewal of the responsiveness of these institutions to the needs and attitudes of the people; and 
(2) Recognition that the cultural, commercial and ethnic diversity of the people is a positive strength and for the fostering of a respect for, and appreciation of, traditional ways of life and culture, including language, in all their richness and variety, as well as for a willingness to apply these ways dynamically and creatively to the tasks of development.

\section{Protection of Rights}

1 Rights and freedoms

The PNG Constitution contains sixteen basic rights and freedoms. These rights fall into three categories: fundamental rights, which apply to all persons and are open to fewer restrictions and qualifications; qualified rights and qualified rights of all citizens.

The basic rights are:

(1) Right to freedom

(2) Right to life

(3) Freedom from inhuman treatment

(4) Protection of the law

(5) Liberty of the person

(6) Freedom from forced labour

(7) Freedom from arbitrary search and entry

(8) Freedom of conscience, thought and religion

(9) Freedom of expression

(10) Freedom of assembly and association

(11) Freedom of employment

(12) Right to privacy

(13) Right to stand and vote for public office

(14) Right to freedom of information

(15) Right to freedom of movement and

(16) Equality of citizens. 


\section{Fundamental rights}

Under section 32, every person has a right to freedom based on law, and, accordingly, has a legal right to do anything that does not injure or interfere with the rights and freedoms of others and is not prohibited by law.

Section 35 declares that every citizen has the right to life. No person shall be deprived of his or her life intentionally except in certain exceptional circumstances allowed under the Constitution, as in the case of the death penalty.

Under section 36, no person shall be subjected to torture (whether physical or mental), or to treatment or punishment that is cruel or otherwise inhumane, or is inconsistent with respect for the inherent dignity of the person.

Section 37 accords protection of the law. This includes requirements that:

(1) Every person has the right to the full protection of the law, especially persons in custody or charged with offences;

(2) No one can be convicted of an offence that is not defined by law;

(3) A person charged with an offence shall be afforded a fair hearing within a reasonable time, by an independent and impartial court;

(4) A person charged with an offence shall be presumed innocent until proven guilty;

(5) A person shall be informed promptly in a language he/she understands; and

(6) A person shall be given adequate time to seek legal representation.

3 Equality of citizens

Section 55 affirms the equality of all citizens. This is perhaps the most profound declaration in the Constitution and it is critical as a strategy in addressing many of the human rights issues in PNG.

\section{Implementation of Human Rights}

Section 57 of the Constitution provides that constitutional rights shall be protected by, and are enforceable in, the Supreme Court or the National Court at the court's own initiative or on application by any person who has an interest in the protection and enforcement, of a human right or, in the case of a person unable to fully or freely exercise his rights, by a person acting on his behalf.

Section 58 provides for compensation or damages to be paid for breach of rights including exemplary damages where appropriate. In many police brutality cases, the courts have awarded exemplary damages against individual police officers found guilty of breaching human rights, as a means of deterrence. 
Despite these constitutional provisions, the enforcement of human rights has not grown considerably. As echoed by former Chief Justice Sir Arnold Amet: ${ }^{6}$

The ability of the judiciary to invoke its inherent powers to protect human rights has so far been minimal even in relation to reported incidents of violations. This can be attributed in large to the continued operation of the inherited adversarial system and the limitation in courts resources.

Discussions about the establishment of a human rights commission have been ongoing for more than a decade, yet it remains a dream. There have, however, been significant developments that may soon see this become a reality. A Final Option paper on the proposed establishment of a PNG Human Rights Commission was developed and presented to stakeholders in 2007, ten years after the National Executive Council endorsed the establishment of such a commission. Prepared by the Department of Community Development and Social Welfare, the Options Paper contains the governing structure for a Human Rights Commission: ${ }^{7}$

The Human Rights Commission will promote and protect observance of and respect for human rights by

educating people about their rights and giving them a place to have complaints about breaches resolved.

It is very exciting that the arrangements are nearly in place.

\section{LEGAL REMEDIES}

\section{A The Courts}

The judicial system of PNG is made up of a hierarchy of courts: the Supreme, National and District or Magistrates Courts and the Village Courts. Section 58 of the Constitution vests the judicial authority of the people in the national judicial system. Section 99(3) provides that the national judicial system consists of a Supreme Court, a National Court with unlimited jurisdiction and other courts. The courts are independent of the executive, legislative and military authorities.

The Supreme Court is the highest court of the land. It is the final appellate court and has original jurisdiction on constitutional matters, including the enforcement of constitutional rights. The National Court is a court of unlimited jurisdiction. It hears most cases and appeals from the district courts established at provincial levels. Village courts are at the lowest level. They apply custom in the discharge of justice. Despite performing a critical role in restorative justice and settling disputes at the village level where approximately ninety per cent of the population live, the exercise of their powers has been the subject of gross human rights abuse. Women and children have generally been victims of these abuses as many customary practices discriminate against them.

$6 \quad$ Ibid, para 1.3.12. See also paras 2.1-2.2.

7 Anthony J Regan, Owen Jessup and Eric L Kwa Twenty Years of the PNG Constitution (Law Book Co, New South Wales, 2001) 62. 
Currently with support from AusAID and UNICEF, the Department of Justice and the AttorneyGeneral, who are responsible for Village Courts, have mounted a nationwide advocacy programme to train Village Court magistrates and officials on human rights. The workload of courts is enormous. With only about 23 judges sitting both at the National and Supreme Courts, the stress on the judiciary is quite evident. The magistracy has, however, had a significant increase in the recruitment of magistrates ensuring a gender balance with appointments. This is not the case with the higher courts with only one female judge.

\section{B Civil Society}

Civil society involvement in human rights issues is not very strong. There are, however, a number of civil groups both local and international that not only challenge the Government and other duty bearers on issues affecting the rights of the public but also educate the public to demand them.

Transparency International takes a lead on corruption issues. Save The Children in partnership with the Government and others has taken on issues of child rights in PNG, and UNICEF has supported reviews of the juvenile justice system and the Child Welfare Act. Oxfam in partnership with local NGOs supports work in women's rights, water and sanitation projects, while the Individual and Community Rights Advocacy Forum (ICRAF) and Family Voice are local NGOs focussed on human rights. The Centre for Environmental Law and Community Rights focuses on environmental issues and the Consultative Implementation Monitoring Council, Meri Kirap, Papua Hahine, Youth Against Corruption, East New Britain Social Action Committee and HELP Resources focus on advocacy and social issues programmes. The Business and Professional Women's Club of Port Moresby and Soroptomist International focus on women's issues.

There is now general recognition that civil society in PNG needs to mobilise to build democratic governance. This move is being strongly supported by donors working with NGOs, media, sports institutions, churches and local government.

\section{PNG RATIFICATION OF INTERNATIONAL HUMAN RIGHTS TREATIES}

PNG has only signed three human rights conventions and has fared badly in its reporting requirements. These are the International Convention on Elimination of Racial Discrimination (ICER); ${ }^{8}$ the Convention on Elimination of all Forms of Discrimination Against Women $(\mathrm{CEDAW})^{9}$ and the Convention on the Rights of the Child (CRC). ${ }^{10}$

8 International Convention on Elimination of Racial Discrimination (21 December 1965) 660 UNTS 195.

9 Convention on the Elimination of all forms of Discrimination Against Women (18 December 1979) 1249 UNTS 13.

10 Convention on the Rights of the Child (20 November 1989) 1577 UNTS 3. 


\section{A Ratified Human Rights Treaties}

PNG ratified the ICER in 1982; however, to date it has not provided its initial report nor any periodical reports as required under the Convention. CEDAW was ratified by PNG in 1995 but a country report is yet to be done. The Department of Community Development (DCD) has been working hard to complete the first country report under CEDAW which is to be presented in 2008. The Department of Justice, and the Office of the Attorney-General was to complete a legislative review for the country report through a UNFPA CEDAW project. $^{11}$

The CRC is the only PNG convention on which PNG has produced and submitted a report to the United Nations Committee on the CRC. The consolidated report was completed and submitted to the UN in 2003. Work undertaken included a review of all legislation and identified thirteen Acts as non-compliant with the CRC. Follow-up work as a result of the country report includes legislative changes to the Juvenile Justice Act and the Child Welfare Act (now referred to as the Lukautim Pikinini Act).

The obligation to produce reports is an essential responsibility of state parties to the nine treaties particularly the developing countries. The conventions expect states to give a genuine reflection of the status of human rights and any other related issues in their respective countries. It is by means of the country reports that the UN and its agencies conduct their assessment of how best assistance can be given, in terms of providing technical as well as financial resources. Difficulties in reporting for PNG include a lack of political will, lack of full time experts, resources and coordination amongst relevant government agencies.

\section{B Domestic Enforcement of International Human Rights Conventions}

Section 117 of the Constitution provides that no treaty, convention, agreement or other act which gives rise to obligations on part of PNG at international law can be entered into by the National Executive Council until it has been tabled in Parliament and Parliament has effected it as domestic legislation. Technically, therefore, the courts cannot make reference to any international conventions not ratified by PNG. However, despite non-ratification of some human rights treaties, judges and lawyers can, pursuant to section 39 of the Constitution, when deciding whether an act or law is "reasonably justifiable in a democratic society", have regard to international human rights conventions. The Constitution, as previously mentioned, also makes provision for the basic principles of human rights in sections 32-58, thus incorporating the general international principles of human rights.

11 This project was not completed, however, when the Officer responsible left in 2005. Unfortunately, her replacement has not been a priority of Government. 
Given the predicament in applying international human rights standards and principles in PNG, the Government has given its approval for a Human Rights Commission to be established in PNG which will see the application of the ratified international human rights conventions become reality.

\section{Non-Ratification}

PNG needs to ratify the ICCPR and the ICESCR so that PNG can be seen to be progressively accepting the whole ambit of international human rights conventions. An inter-agency committee consisting of relevant government agencies including the Department of Justice and the AttorneyGeneral prepared a Policy Submission for endorsement by Cabinet for the ratification of the ICCPR and ICESCR in 2006. The submission was signed by both the Minister for Foreign Affairs and the Minister for Justice.

\section{LEGAL AND ADMINISTRATIVE REMEDIES FOR RIGHTS BREACHES}

\section{A Legal Remedies}

The Supreme Court has original jurisdiction in the enforcement of human rights and has already set a precedent for doing so. In the case of Miriam Wilingal, ${ }^{12}$ an 18 year old girl was given against her will to another tribe as part of compensation payment, together with pigs and money in settlement of a tribal dispute. Upon reading of her predicament in the newspaper, ${ }^{13}$ the human rights non-governmental agency ICRAF made an application to the Supreme Court under section 57 of the Constitution to enforce her rights, seeking a declaration that the customs and actions were inconsistent with the Constitution and repugnant to the general principles of humanity and thus unlawful. The Supreme Court decided in favour of ICRAF's application and granted the claimant her freedom.

Damages claims for human rights abuse can be made in the National Court. Claims against the state for police brutality are the most common claims in this area. Despite losing millions of state funds in police brutality cases, abuses continue, many without any repercussions. Parties can also seek protection in the District Court against anyone harming or intending to harm them. In particular, victims of family and domestic violence can seek restraining orders under section 109 of the District Courts Act to prevent others from harming them.

Village Courts unfortunately are problematic. As previously mentioned, they do not have a clean record for enforcing or upholding human rights. As they can only apply custom, many human rights abuses occur in the discharge of their functions. It is an area that is currently being reviewed and supported through advocacy programmes. There is a need to delegate some human rights

12 Case of Miriam Wilingal (1996) vol OS 289.

13 "Girl Sold in Death Compensation" (11 December 2007) The National Newspaper. 
enforcement powers to the lower levels of courts to help deal with the backlog of outstanding human rights cases in the National and Supreme Courts and to make redress easier to obtain.

\section{B Administrative Remedies}

Administrative remedies for breach of human rights are also dealt with through agencies such as the Ombudsman Commission and the Police Public Complaints Unit for police abuse. Many human rights cases are initially taken up by civil society then channelled through these offices.

\section{The establishment of the Ombudsman Commission}

The Ombudsman Commission is a highly esteemed constitutional office in three important capacities: first, as a traditional ombudsman - receiving and dealing with complaints of administrative misconduct by public officials; secondly, as a de facto human rights commission dealing with human rights violations under its discriminatory practices jurisdiction, and thirdly as an anti-corruption watchdog policing the Leadership Code.

The CPC when recognising the need for an ombudsman, thought that the "traditional" ombudsman concept was needed by the new nation. The specific reasons given for establishing an ombudsman institution were:

(1) Traditional customs and beliefs (which imposed restrictions on land use, human relations and personal obligations) were no longer adequate to cope with the increasingly interdependent nature of PNG's societies and the widespread activities of government;

(2) The "modern control system" had therefore become too complex;

(3) Those exercising public powers could not be adequately supervised;

(4) Careful superintendence of a lot of government decisions had become difficult;

(5) Negligence or wilful abuse of administrative power had resulted in hardship and injustice; and

(6) The court system was restricted in the remedies it could provide, and was still operating on the adversarial model.

The Ombudsman Commission was envisaged as the institution that would provide a quick, flexible means of redress for aggrieved citizens suffering from administrative injustice. The CPC stressed, however, that the Commission was not intended to take the place of the courts: ${ }^{14}$

We believe that our Ombudsman Commission should have more the supervisory and investigatory role in relation to those vested with the administrative power to make decisions, rather than for the Commission to be seen as a substitute for the courts.... This does not mean that we see the Ombudsman

14 Constitutional Planning Committee, above n 5, paras 11.8-11.9. 
as in any way less significant. In fact, we recognise that sometimes access to courts is difficult, for psychological or other reasons, and that the courts are not always able to provide redress sufficiently promptly or in the most effective way. In such situations, the ombudsman could be the more appropriate channel for the redress of grievances.

In this traditional role, the Ombudsman Commission was seen as the institution that would be available to assist ordinary people throughout the country who felt aggrieved by actions or omissions of the bureaucracy or of any institution of Government.

\section{Functions of the Ombudsman Commission}

The Ombudsman Commission has three primary functions and, in addition, a number of subsidiary functions. Its primary functions include the investigation of alleged wrong conduct and defective administration by governmental bodies, of alleged discriminatory practices by any person or body, and of alleged misconduct in office under the Leadership Code.

The "traditional" function allows the Commission to perform the role of a traditional ombudsman by investigating, either from a complaint or its own initiative, administrative practices and decisions of governmental bodies which may be unreasonable, unjust or oppressive.

Anti-discrimination is the second function. Here the Commission performs the role of what other jurisdictions call anti-discrimination or equal-opportunity commissions. In this context, its jurisdiction is not restricted to the investigation of governmental bodies. Section 219(1)(c) speaks simply of investigation of discriminatory practices "within the meaning of a law prohibiting such practices."

There are two relevant laws in this area: the Discriminatory Practices Act (chapter 269), and the HIV/AIDS Management and Prevention Act 2003, which apply to all bodies and persons. Though the Commission was established primarily as a means of imposing accountability and control on the public sector, this area of jurisdiction gives it an extra dimension in terms of its relationship with the private sector.

Under its Leadership Code jurisdiction, the Commission performs the role conflict-of-interest commissions assume in other countries. Further, in the absence of an independent, adequately resourced anti-corruption body, it has also become a de facto anti-corruption agency. It has been able to combine its extensive powers under the Leadership Code, together with the exercise of powers as a traditional ombudsman institution, in the fight against corruption in PNG. Under its subsidiary functions, the Commission has, among other things, the power to make special requests to the Supreme Court on questions of constitutional interpretation, and an implied power to enforce the Basic Rights of the Constitution. 


\section{The human rights roles of the Ombudsman Commission}

In March 2005, the Ombudsman Commission established a new unit to deal specifically with human rights and discriminatory practices. This unit is now the focal point within the Commission for all human rights issues and has been actively involved in a lot of national human rights strategies, such as the drive for the establishment of the PNG Human Rights Commission and the Law and Justice Sector Human Rights Strategies. In addition the Ombudsman Commission through the unit is now the executing agency for a second UNDP Human Rights Project.

Generally, the Ombudsman Commission has the mandate to address human rights under its Administrative Complaint Investigation and special references. Under its traditional ombudsman role, the Ombudsman Commission receives complaints about human rights violations perpetrated by public officials, which in most cases have involved members of the disciplined forces. These complaints are investigated and where the complaint is sustained the Commission issues a recommendation to the head of the Department concerned to deal with the matter. Where human rights violations have been caused by private actors, the Ombudsman Commission generally lacks jurisdiction to deal with such complaints.

The Commission is one of a limited range of public bodies authorised by the Constitution to make special references to the Supreme Court to seek the Court's binding opinion on questions relating to the interpretation or application of constitutional laws. In this respect, the Ombudsman Commission has been authorised to maintain a watching brief over the nation's constitutional development. By virtue of this "hotline" to the Supreme Court, the Commission has become, to some extent, a guardian of the Constitution. Since independence, it has been a fairly regular referrer of constitutional questions to the Supreme Court. For example, amongst other things, it has tested the constitutional validity of the Internal Security Act $1993^{15}$ and the long adjournment of Parliament. The Commission has the discretion to use this provision to seek Supreme Court interpretation of the constitutionality of any law that appears to unnecessarily restrict or interfere with a constitutionally entrenched right.

\section{The enforcement of Basic Rights}

Section 57 of the Constitution gives the Commission the power to enforce Basic Rights. Section $57(2)$ suggests that any persons "with an interest... in the maintenance of the principles commonly known as the Rule of Law" ought to be given standing to make applications on behalf of others in the Supreme Court or the National Court for enforcement of the Basic Rights. The Ombudsman Commission would appear to fall squarely within this category of persons. However, the Commission has never exercised this power. When it has investigated alleged abuses of the Basic

15 Re Internal Security Act; Reference by the Ombudsman Commission [1994] PNGLR 341. 
Rights, it has confined its role to preparing reports and recommendations. It has never actively pursued the results of its investigations through the courts.

The rationale for this approach lies in the Commission's perception of its role when it undertakes a human rights investigation. It performs the role of an independent investigator. Although it acts on a complaint, it is not acting for the complainant. The complainant is not its client. The Commission therefore has no paramount duty to the complainant. It would be inconsistent with the Commission's impartiality for it to assume the adversarial role required of it, if such matters were pursued through the courts. The other reason for reluctance to engage in human rights litigation is that there is another institution that is far better equipped constitutionally (if not in terms of resources) to deal with this task: the Office of the Public Solicitor.

This may appear to be a setback as far as human rights enforcement is concerned; however there is an increasing interest in using the powers of the Commission to pursue human rights matters in court where it is in the public interest to do so rather than as a legal representative for a particular individual.

\section{General awareness and education}

The Commission through its External Relations Programme has been involved in raising human right awareness as a means of helping governmental bodies to fulfil their duties under law, and to increase public knowledge about the promotion and protection of human rights.

Two projects have been undertaken so far. First, a Human Rights Advocacy and Monitoring Project has been conducted, focusing on three major outputs: a nationwide advocacy campaign targeted at raising awareness of human rights among marginalised groups and rural communities; a needs assessment report of the national human rights needs; and capacity building for police and other agencies, including the Ombudsman Commission. The second project specifically complements the setting up of the PNG Human Rights Commission in terms of advocacy and awareness, training of legal and media personnel and strengthening institutional mechanisms for the promotion and protection of human rights.

It is clear that the Ombudsman Commission has been doing a lot under its mandated powers to promote and protect human rights. In terms of enforcement, the Commission is restricted as discussed above. The Commission considers its major role to be ensuring that governmental bodies and other state actors understand and respect human rights, and in turn also ensuring that the public is aware of these rights so that duty bearers are accountable to the public. 


\section{RULE OF LAW}

\section{A Separation of Powers}

PNG follows the Westminster system of government with three principal arms: the executive, legislature, and judiciary, which were inherited from the colonial experience. Each of these functions has been entrusted to the appropriate branch of government.

Section 99 of the Constitution provides that the National Government consists of the National Parliament, an elected legislature with, subject to constitutional laws, unlimited powers of lawmaking; the National Executive; and the National Judicial System, consisting of a Supreme Court of Justice, a National Court of unlimited jurisdiction, and other courts. It is also a principle of this section that the respective powers and functions of the three arms shall be kept separate from each other: ${ }^{16}$

It is clear that the Constitution contemplates a general separation of powers between the three arms of government, the executive, the legislature and the judiciary. As a parliamentary system with an executive responsible to Parliament, the separation of the arms cannot be rigid. But the separation principle remains of basic importance in the Constitution and prohibits incursions by one arm of the government upon the basic functions of another.

\section{B Judicial Independence}

The Constitution provides for an independent judiciary, and the courts are independent of executive, legislative and military authorities. The judicial authority of the people is vested in the national judicial system. I am proud to say that the independence and integrity of the judiciary is intact despite significant national turmoil including constitutional crises.

Section 59 of the Constitution requires judges to be impartial and neutral in the discharge of their duties by applying principles of natural justice. They must apply the minimum requirement of the duty to act fairly and, in principle, be seen to act fairly. "Pursuant to this principle, the courts have laboriously laid down the rules of the underlying law applicable to natural justice in PNG."17

\section{Access to Justice}

Access to justice includes public interest litigation, the right to legal aid, and obstacles to access to justice. It is unfortunately not readily available, though mandated by law. Constitutionally, the Office of the Public Solicitor is to provide legal services for the public at large. Legal aid, however, is almost non-existent for this office (except for those charged with criminal offences) as it is both

16 Re Motor Traffic Act 1982 [1982] PNGLR 122.

17 Regan, Jessup and Kwa, above n 7, 101. 
critically under-funded and under-staffed. Other obstacles include excessive private lawyer fees, inaccessibility to courts and long and cumbersome court processes.

Several NGOs like ICRAF and Family Voice offer basic legal aid but even they are not able to meet the increasing demands placed on them. Public interest litigations are few and varied, being mainly taken on by NGOs with the very limited resources that they have.

\section{Open Justice}

Section 37(12) of the Constitution provides that except with the agreement of parties, or by order of a court in the interest of national security, proceedings in any jurisdiction of a court and proceedings for the determination of any civil right or obligation before any court or any other authority, including the decision of the court or any other authority, shall be held in public. The public and media are generally allowed in most court proceedings except in certain cases concerning for example, children in adoption cases.

\section{CULTURE AND LANGUAGE}

\section{A Language}

The fifth Goal identified in the Constitution is to achieve development primarily through recognition that the cultural, commercial and ethnic diversity of the people is a positive strength and to foster a respect for, and appreciate, traditional ways of life and culture, including language, in all their richness and variety. As previously mentioned, PNG has over 860 different languages and about the same number of tribes. Tok Pisin and Hiri Motu are the two main spoken languages and English is the official language. Most Papua New Guineans are bilingual but many are multilingual, speaking anything up to six languages.

Sadly however, many children in urban areas and of mixed parentage (parents from different provinces) cannot even speak the mother tongue of their parents. Further, there has been no clear effort to preserve the indigenous languages. The only effort so far is that of the work of bible translators placed by the Summer Institute of Linguistics (SIL) ${ }^{18}$ around PNG to study, learn, document and translate the Bible into local languages. At the recent launch of the 2008 International Year of Languages, it was reported by SIL that they have recorded an increase in the number of languages which cannot be redeemed. ${ }^{19}$ The most formal move to preserve languages is the push to

18 SIL International is a faith-based organisation that studies, documents, and assists in developing the world's lesser-known languages. SIL staff share a Christian commitment to service, academic excellence, and professional engagement through literacy, linguistics, translation, and other academic disciplines. SIL makes its services available throughout the world without regard to religious belief, political ideology, gender, race, or ethnic background.

19 The National (11 April 2008) 5. 
teach children at the elementary level in their mother tongue, at least for the first three years of their formal education. Bridging to English follows soon after.

\section{B Tensions Between Culture and Other Rights}

Custom plays a particular role in the context of PNG and is in fact recognised under section 9 of the Constitution. However, its adoption, application and enforcement are subject to certain exceptions. Schedule 2.1 of the Constitution provides for the recognition of custom through its adoption, and shall be applied and enforced, as part of the underlying law.

The Customs Recognition Act 1963 sets out the application of custom. ${ }^{20}$ It provides that custom shall be recognised and enforced by, and may be pleaded in, all courts except where its recognition would result in injustice or would not be in the public interest or in a case affecting the welfare of a child under the age of 16 years, its recognition or enforcement would not be in the best interest of the child.

Whilst there is concern about rights being breached by custom, there is also the sad fact that many of the traditional cultures have either eroded or do not exist anymore. For example, in the author's home area, barter trade between different tribes has stopped. Large ocean canoes used for trading are not built anymore. The loss is enormous, canoe-making skills and exchange of traditional monetary items like clay pots and wooden dishes are gone together with the loss of important relationships along traditional trade routes.

Another particular area of concern is the changing value of "men" in PNG. Traditionally, men were valued on the basis of being initiated, the ability to build a house, and look after a family, make a garden, go hunting and fishing, have ability to perform customary dances, rituals and knowledge of land boundaries. In the modern setting, the value of a man is dependent on whether or not he has a university degree, the type of car he drives, how many houses he has, what school his children attend and how much money he has in the bank.

This has totally disempowered men, particularly young men who live in towns and has resulted in, amongst other things, abuse of drugs, alcoholism, and domestic violence. Placing men back into the village would give them the opportunity to know that there is a different empowering system that recognises their value as men and they need not be destructive both to themselves and their community to get that recognition. Accommodating "modern" aspirations within the village context is a challenge in itself.

Compulsory learning of the mother tongue called tokples in elementary schools, promotion of cultural activities in schools, the celebration of several regional cultural shows including the Hiri

20 Customs Recognition Act 1963, ch 19. 
Moale and the Traditional Masks Festivals, the Goroka and Hagen cultural shows are examples of how PNG is trying to preserve its cultures.

\section{Education}

There is no legally enforceable right to education in PNG. Children can be denied an education because parents are too poor to pay the school fees or there are just not enough spaces at the schools according to school officials. Girls can be denied an education just because they are female. Currently, only 53 per cent of children aged 6 to 14 years attend school. ${ }^{21}$ An estimated 686,000 children do not attend school. The Basic Education Sector comprises 6,086 elementary schools (grades Prep to 2); 3,198 primary schools (grades 3 to 8); 29,466 teachers (of which 43 per cent are female) and 783,727 students (of which 45 per cent are girls). ${ }^{22}$

The quality of education is poor. Factors contributing to this problem range from lack of furniture and basic resources in classrooms to school buildings being poorly maintained, poor teacher training, lack of government supervision and weak administration of education. Despite ratifying the CRC, PNG is yet to meet its educational obligations to children.

The second National Goal provides for all citizens to have an equal opportunity to participate in, and benefit from, the development of PNG in fulfilment of his or her real needs and aspirations. Education is a key factor in making this goal a reality, however, despite PNG's best efforts to achieve Millennium Development Goals such as improved functional literacy rates, a relevant curriculum and a reduction in poverty, these goals are a long way from being achieved. To achieve the international benchmark of Education For All (EFA), PNG not only focuses on a high quality, relevant education system, but also a flexible community-based informal system of learning, covering both early childhood and adult education.

Basic education is a key requirement under the Government's Medium Term Development Strategy (MTDS). ${ }^{23}$ PNG's primary objective is to ensure an increase in the number of children receiving basic education up to Grade Nine in line with the international goal of Universal Primary Education. Programmes including implementing curriculum reform, teacher training, improving infrastructure and rural education facilities are now being undertaken to support this goal.

21 Estimated Net Enrolment Rate based on preliminary results of the 2007 National School Census.

22 Department of Education Annual Report 2006.

23 The Medium Term Development Strategy [MTDS], which will cover the six-year period from 2005 to 2010 , is Papua New Guinea's overarching plan for economic and social development. The primary role of the MTDS is to translate the Government's Programme for Recovery and Development into a series of broadly defined policy interventions that are soundly based, mutually supporting and affordable. The MTDS will serve as the Government's apex planning, policy and resource allocation framework. 
The importance of a relevant curriculum for PNG's development has also been recognised and is now part of the National Education Plan. Over the years, a number of studies have questioned the relevance of PNG's education curriculum, finding it to be irrelevant to the majority of young Papua New Guineans in terms of preparing them for rural livelihoods. Job opportunities in the formal sector are very limited thus the need to focus on technical or vocational training that will equip students in cash cropping, small scale farming and other income earning opportunities that will enable them to live in their villages but still earn an income.

The ability to read is the key to development at personal, local, and national levels. There is also an increased emphasis on programmes to improve adult literacy, through the promotion of functional literacy programmes. Because adult education has been neglected since independence, PNG now faces a major constraint to development with around half of the population being functionally illiterate, and dependent on a traditional skill base. The Government has recognised the urgent need to equip Papua New Guineans with new knowledge and skills, and to enable them to participate more meaningfully in the development process. It has therefore introduced programmes such as the Employment Oriented Skills Development Project to address these needs. Informal education is community based and NGO-driven, but is done in partnership with the formal education institutions like the vocational and technical schools.

Some initiatives have been taken to encourage education of girls. The Accelerated Girls Education Project, initiated through the Department of Education and supported by UNICEF, is a good example of how enrolment of girls in schools is being promoted. Other initiatives include the push for equal participation of females in training and scholarships.

\section{The Right to Health}

\section{Background}

PNG's health status is the lowest in the Pacific Region. The main health problems facing PNG have remained unchanged over the last fifteen years and are particularly acute in rural areas. Six diseases that can be treated inexpensively at rural aid posts or outpatient clinics by trained health extension officers or nurses continue to cause over 40 per cent of deaths of people under 45 years of age. These include pneumonia, malaria, diarrhea, tuberculosis, measles and anemia. Further, meningitis, typhoid and the leading causes of maternal mortality account for another 10 per cent of deaths. PNG now has a generalised epidemic of HIV/AIDS. Access to clean water and sanitation also remain fundamental health issues both in rural and urban areas.

Health services in PNG are provided by the Government and the churches and are primarily financed by public funds. However, poor road infrastructure and rugged terrain coupled with corruption, funding problems and lack of coordination pose extremely difficult challenges to delivering effective health services. 
As with education, there is no right of access to health in PNG. The National Goals and Directive Principles declare as the first Goal that every person to develop as a whole person through improvement in the level of nutrition and the standard of public health to enable people to attain self-fulfilment. This in itself places an obligation on the Government to ensure the provision of health services as a minimum pre-condition to good health. Services in this area are however, minimal or non-existent.

Another example of the lack of attention to the health of Papua New Guineans is the indifference Government shows towards the importation of food from Asia and elsewhere. Regulation of imported food is not rigorously maintained. For example, lamb flaps are imported to PNG with almost no restrictions. This contributes to health problems including a rise in heart disease.

\section{Primary health care}

The Government's focus is now on primary and preventive health care, with priority being given to services in rural areas. Working with other partners, including decentralised governments, churches, NGOs and international development partners, the Government is primarily aiming to support aid posts and health centres with appropriately trained staff, effective supervision, regular community outreach and mobile clinics or patrols and supplies of drugs and materials. Accessibility to health services is, however, not guaranteed. In the public health system, corruption adds to the dilemma. Critical shortages of drugs mean that people in rural areas die unnecessarily.

Recently, the Chairman and President of the PNG Medical Board and Medical Society, Professor Matthias Sapuri, called on the Government to consider new ways to improve delivery of health services. He noted that the current health care delivery system is no longer appropriate to the demand and needs of PNG and there is an inability of health care workers to cope when there is a breakdown in the system: ${ }^{24}$

'As an example, last Friday morning, ten mothers delivered their babies on the floor of the Port Moresby

General Hospital's labour ward,' he said. He said even the accident and emergency unit (AEU) did not have the space and the patients slept all over the floor. He said the old system allowed for congestion and overflow of patients leaving limited time for tertiary health care, professional training and quality patient care and management.

This is a reflection of the main hospital in PNG's capital city. It is worse in the rural areas where people are needlessly dying from lack of medicine and accessibility to a health centre or hospital. Hospital fees, the inability to afford private medical care, and the lack of a government medical scheme mean that the majority of the population cannot access health services, no matter how basic. Whilst there may be no reported cases of discrimination based on health status, with the increase of

24 The National (26 February 2008) 4. 
HIV/AIDS, victims are slowly reporting refusals of treatment. This is, however, prohibited under the HIV/AIDS Management and Prevention Act 2003.

\section{HIV/AIDS}

PNG also faces another critical challenge. It is now confronted with an HIV/AIDS epidemic: ${ }^{25}$

That threatens not only the country's future development prospects, but risks undermining the development achievements of the post-Independence period. Aside from the personal grief of afflicted individuals, families and carers, HIV/AIDS also threatens PNG's economic prospects, including by eroding the skills base of the economy. Arresting the spread of HIV is a fundamental objective of the current government otherwise the results would be catastrophic.

So far there are a total of $40,000-60,000$ people living with HIV/AIDS. The figure is, however likely to be higher as there is currently no mechanism in place to report HIV-related deaths nor is testing compulsory. PNG also has the one of the highest rates of HIV/AIDS in the Pacific.

\section{E Environment}

Whilst PNG has made "environment" a legal issue, it is not a constitutional right. Goal Four of the National Goals and Directive Principles provides for PNG's natural resources and environment to be conserved and used for the collective benefit of all, and be replenished for the benefit of future generations. It calls for:

(1) Wise use of our natural resources and the environment in and on the land or seabed, in the sea, under the land, and in the air, in the interests of our development and in trust for future generations;

(2) Conservation and replenishment, for the benefit of ourselves and posterity, of the environment and its sacred, scenic, and historical qualities; and

(3) All necessary steps to be taken to give adequate protection to our valued birds, animals, fish, insects, plants and trees.

It is clear that this Goal laid the foundation for developing PNG in a sustainable way. To show its commitment to protecting the environment, PNG has ratified both the Convention on Climate Change and the Convention on the Protection of Biological Diversity as an indication of its willingness to be a partner in the global action.

Domestically, three pieces of legislation govern the use of environment: the Environmental Planning Act 1978, the Environmental Contaminants Act 1978 and the Conservation Areas Act 1978. The Environmental Planning Act is the main piece of legislation balancing development and environment. The Environment Contaminants Act is intended to control the release into the 
environment of any substance or form of energy which might adversely affect beneficial use of the environment. The Act creates a range of pollution offences, including the pollution of waters, the atmosphere and the land, as well as littering, breaking glass or noise pollution. The Conservation Act encourages the active participation of people in the conservation of their own resources.

Experience has shown, however, that the opposite is true. A series of case studies by one of PNG's leading environmental NGOs, the Centre for Environmental Law and Community Rights, shows the reality of human rights abuses that come with the destruction of the environment at the expense of landowners and the indifference Government shows towards these issues. The studies demonstrate the link between large-scale logging and human rights abuse, highlighting that despite legal protections, large-scale logging is routinely undermining human rights of landowners. The studies reveal: ${ }^{26}$

(1) Cases of arbitrary detention and physical brutality by police against landowners, constituting an abuse of civil rights, including the right to life, personal liberty and the right to be free from torture and cruel, inhuman and degrading treatment;

(2) Intimidation and abuse of women, constituting the denial of women's right to be free from violence;

(3) Serious flaws in the Incorporated Land Group Process, resulting in the denial of the right of landowners to access accurate information, make informed decisions and to participate effectively in decisions about their land;

(4) The contamination of food and water sources by large scale logging, constituting the denial of economic and social rights, including the right to health and the right to an adequate standard of living;

(5) Unjust working conditions, constituting the denial of the right to a decent working environment; and

(6) The destruction of cultural sites by logging, resulting in the denial of the right of communities to enjoy their own culture and use their land for cultural and spiritual purposes.

The right to protect the environment is not enforceable in the same way as the right to vote, or the right to freedom, or the right to freedom of movement. As a National Goals and Directive Principle, it is non-justiciable. The question remains: do the Goals and Directive Principles give Papua New Guineans sufficient rights to a safe and healthy environment? By making it enforceable

26 Centre for Environment Law and Community Rights and Australian Conservation Foundation "Bulldozing Progress, Human Rights Abuses and Corruption in Papua New Guineas Large Scale Logging Industry" (2006) www.illegal-logging.info/. 
PNG could ensure that everyone, especially global corporations, be more careful and use best practice from the Rio Summit to look after the environment.

\section{CONCLUSION}

PNG has not made much progress in advancing or protecting the rights of its people. The establishment of the human rights commission endorsed over a decade ago remains unattended to by Government. The advancement of women's rights in the country and attendance by Government to socio-economic issues lacks the zeal and drive envisioned by the founders of the Constitution.

Abuse of the environment and the lack of interest or indifference by Government have resulted in the loss of land and malicious destruction of the environment, threatening the very life of the people. Foreign-owned companies are not being held to account for the damage they are causing. Inaccessibility to basic health and education coupled with illiteracy and lack of access to legal aid means there is no redress for the public at the end of the day.

PNG has not yet established a human rights commission but it does have a framework and legislation that support human rights. What it lacks is the political will to implement its obligations. PNG needs to look not only at its commitment to uphold the human rights of its people but must also support all initiatives to educate people on their rights as a strategy to ensure that the people are not left continuously ignorant of these issues. 
